\section{Salivary stones: symptoms, aetiology, biochemical composition and treatment}

\author{
S. Kraaij, ${ }^{1,2}$ K. H. Karagozoglu, ${ }^{1}$ T. Forouzanfar, ${ }^{1}$ E. C. I. Veerman ${ }^{2}$ \\ and H. S. Brand ${ }^{* 1,2}$
}

\section{VERIFIABLE CPD PAPER}

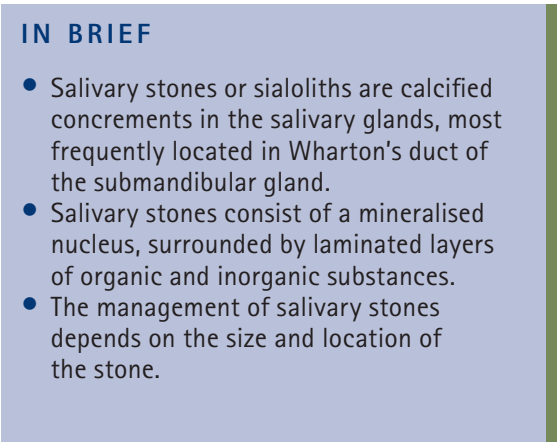

IN BRIEF concrements in the salivary glands, most frequently located in Wharton's duct of submandibular gland.

nucleus, surrounded by laminated layer of organic and inorganic substances.

- The management of salivary stones depends on the size and location of the stone.

\begin{abstract}
Salivary stones, also known as sialoliths, are calcified concrements in the salivary glands. Sialoliths are more frequently located in the submandibular gland (84\%), than in the parotid gland (13\%). The majority of the submandibular stones are located in Wharton's duct (90\%), whereas parotid stones are more often located in the gland itself. Salivary stones consist of an amorphous mineralised nucleus, surrounded by concentric laminated layers of organic and inorganic substances. The organic components of salivary stones include collagen, glycoproteins, amino acids and carbohydrates. The major inorganic components are hydroxyapatite, carbonate apatite, whitlockite and brushite. The management of salivary stones is focused on removing the salivary stones and preservation of salivary gland function which depends on the size and location of the stone. Conservative management of salivary stones consists of salivary gland massage and the use of sialogogues. Other therapeutic options include removal of the stone or in some cases surgical removal of the whole salivary gland.
\end{abstract}

\section{INTRODUCTION}

Salivary stones or sialoliths are calcified structures or concretions located in the parenchyma or ductal system of the salivary glands (Fig. 1). Sialolithiasis is a common salivary gland disorder characterised by the obstruction of the salivary secretion, accounting for approximately one third of salivary gland disorders. ${ }^{1}$

Most cases of sialolithiasis present with symptoms such as pain and swelling in the submandibular or parotid region during mealtime (Table 1). Swelling is the most common symptom in submandibular stones, followed by pain. Three percent of the patients with a submandibular stone have no symptoms. Swelling is also the most common symptom of a parotid gland stone. Pain is present in approximately half of the patients with a parotid stone and only $1 \%$ has no symptoms. ${ }^{2-4}$ In general, pain and swelling are more pronounced when a stone is located in the duct than when the stone is located in the gland itself. ${ }^{2}$

'Departments of Oral and Maxillofacial Surgery/Oral Pathology, VU University Medical Centre/Academic Centre for Dentistry Amsterdam (ACTA), Amsterdam, The Netherlands: ${ }^{2}$ Department of Oral Biochemistry, Academic Centre for Dentistry Amsterdam (ACTA) Amsterdam, The Netherlands

${ }^{*}$ Correspondence to: H. S. Brand

Email: h.brand@acta.nl

Tel: +31 205980897

Online article number E23

Refereed Paper - accepted 2 September 2014

DOI: 10.1038/sj.bdj.2014.1054

${ }^{\circledR}$ British Dental Journal 2014; 217: E23
Characteristics for sialolithiasis are episodes of pain and swelling during mealtime which may persist for a few hours, followed by long episodes of remission (weeks or months). ${ }^{2,5}$ The pain and swelling are caused by the obstruction of the salivary flow in the affected gland, resulting in accumulation of saliva and a subsequent increase in intraglandular pressure. In incomplete obstruction of the duct, saliva can seep through or around the sialolith. In these cases, a salivary stone can be symptomless and these stones may be an incidental finding on a dental panoramic radiograph. ${ }^{6}$

The duration of symptoms before patients present in a clinic varies considerably. The mean duration of symptoms is approximately five years and four months for submandibular stones and four years and ten months for parotid stones. ${ }^{7}$ One third of the patients with sialolithiasis will present within the first six months of symptoms. ${ }^{2}$

In $90 \%$ of the patients with a salivary stone, infection of the affected gland is present and in $12-18 \%$ a purulent discharge is seen., ${ }^{2,8,9}$

The salivary flow rate of patients with sialolithiasis decreases when the mass of the sialolith increases. The mean submandibular salivary flow rate in patients with a submandibular stone was 38\% lower compared to healthy individuals $(0.18$ and $0.29 \mathrm{ml} / \mathrm{min}$, respectively). ${ }^{10}$ Nishi et al. ${ }^{11}$ observed a mean reduction of $84 \%$ of the salivary flow rate of the affected submandibular gland compared to the unaffected contralateral gland.

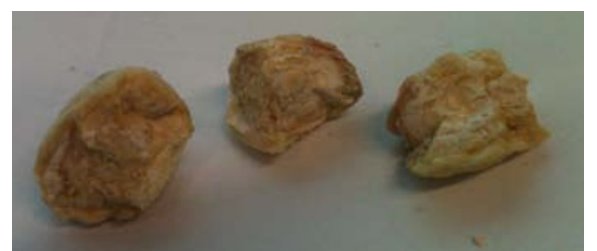

Fig. 1 Fragmented sialolith, removed from the submandibular gland

\begin{tabular}{|c|c|c|}
\hline & $\begin{array}{l}\text { Submandibular } \\
\text { stone }\end{array}$ & $\begin{array}{l}\text { Parotid } \\
\text { stone }\end{array}$ \\
\hline Swelling & $86-92 \%$ & $88-93 \%$ \\
\hline Pain & $35-47 \%$ & $88-93 \%$ \\
\hline $\begin{array}{l}\text { No } \\
\text { symptoms }\end{array}$ & $3 \%$ & $1 \%$ \\
\hline
\end{tabular}

Long-term obstruction of the salivary flow may increase intraglandular pressure, leading to destruction of the salivary gland and formation of connective tissue. Dissected submandibular salivary glands showed periductal and interlobular fibrosis, lymphocytic infiltration and atrophy of the acinar cells. ${ }^{12-14}$

Salivary stones usually have a yellow or yellow-brown colour, and vary greatly in size and weight. The weight of salivary stones varies from $1 \mathrm{mg}$ to almost $6 \mathrm{~g}$, with an average weight of $300 \mathrm{mg} .{ }^{15}$ Generally, submandibular stones are slightly larger than parotid stones (Table 2). ${ }^{3-5,16}$ Approximately 59\% of the stones have a diameter between 2.1 and $10 \mathrm{~mm}$ and $7.6 \%$ are larger than $15 \mathrm{~mm}$ in section. ${ }^{17}$ 
Salivary stones are classified as 'giant salivary stones' when the diameter is $15 \mathrm{~mm}$ or more in any direction or when the weight is $1 \mathrm{~g}$ or more. Giant salivary stones are usually located in the glandular parenchyma and are rarely found in Wharton's or Stenson's ducts. ${ }^{18}$

The shape of a salivary stone depends on the location from where the stone originates. Stones originating from the ductal system are mostly elongated, whereas stones originating from the hilus or gland are round or oval. ${ }^{1,2,17,19}$ Generally, submandibular stones have a smoother surface whereas parotid stones have a more irregular surface. ${ }^{3}$

\section{Incidence and distribution between glands}

The mean incidence of hospital admission for patients with symptomatic sialolithiasis in the United Kingdom is 27.5 per million per year, and the estimated prevalence of sialolithiasis is $0.45 \%$ in an average life expectancy of 76 years. ${ }^{16}$ This percentage is considerably lower than the previously reported $1.2 \%$ based on post-mortem research by Rauch and co-workers. ${ }^{20}$

Sialolithiasis is most common in the fourth and fifth decade of life. The average age of patients with submandibular stones is slightly younger than that of patients with parotid stones (Table 2). ${ }^{2-4,21}$ Sialolithiasis in minor salivary glands seems to occur later in life, in the fifth to eight decades. Sialolithiasis in the first decade of life is rare, and encompassing $2.9 \%$ of all cases. ${ }^{17}$ Sialolithiasis is familial in approximately $1 \%$ of the cases. ${ }^{3}$ Bullock et $a .^{22}$ reported on a family in which three successive generations (grandmother, mother and grandchild) had salivary stones in both submandibular and parotid glands.

Until the nineties of the last century, most studies reported a male predominance of sialolithiasis, varying from 2.5:1 to 1.2:1. .,8, $17,23,24$ However, more recent studies reported an almost equal distribution of salivary stones between men and women. ${ }^{16,25}$

Salivary stones are equally distributed between the left and right side of the oral cavity. ${ }^{2,5,17,26,27}$ In $70-80 \%$ of the patients a single stone is found, in 20\% two salivary stones are found and in roughly 5\% three or more salivary stones are found in the affected salivary gland. ${ }^{17}$

The submandibular gland is affected in 72 to $95 \%$ of the cases, whereas the parotid gland is only affected in 4 to $28 \%$ of the patients. Salivary stones in the sublingual and minor salivary glands are rare, and comprises only 0.4 to $7 \%$ of all cases. ${ }^{2,3,5,17,20,25}$

Submandibular stones are usually located in the duct (80-90\%), of which $57 \%$ is located in the hilum and 34\% is located in the distal duct. Ten percent of the submandibular stones is located in the gland itself., ${ }^{3,28}$ Twenty-three percent of the parotid stones is located in the parenchymal system, 13\% is located in the hilum and 64\% is located in the distal duct.

Sialoliths of the minor salivary glands are most frequently located in the upper lip (47\%), the buccal mucosa (35\%) and lower lip (10\%). Only a few case reports described sialolithiasis of the minor salivary glands of the tongue and palate. ${ }^{1,12,21,29-31}$

\section{AETIOLOGY}

The exact aetiology of salivary stones is not completely understood, and various hypotheses have been put forward. These hypotheses include the agglomeration of sialomicroliths, anatomical variations of the salivary ducts and an altered biochemical composition of saliva. It is considered that salivary stasis or decreased salivary flow contributes to the precipitation of calcium. ${ }^{14}$

\section{Sialomicroliths}

A sialomicrolith is a microscopic concretion in a salivary gland. These concretions consist of crystals containing calcium and phosphorus, as well as organic secretory material in granular form and necrotic cell residues. ${ }^{28,32}$ Sialomicroliths have been identified in serous acinar cells, striated ductal cells, lumen and interstitium of almost all normal submandibular glands and in $10-20 \%$ of the normal parotid glands. ${ }^{21,33-37}$ The observation that sialomicroliths were more frequently found in the submandibular gland may correspond to a higher calcium concentration in submandibular glands. ${ }^{36}$ The size of microcalculi differs per place of origin; intracellularly sialomicroliths can be up to $25 \mu \mathrm{m}$, in acinar lumen up to $70 \mu \mathrm{m}$ and interstitially up to $35 \mu \mathrm{m} .{ }^{14,33}$

The incidence of sialomicroliths is related to the age of the patient, with an increased sialomicrolith formation in the intraglandular duct system of the submandibular gland in patients of 40 years or older. ${ }^{28,34}$ Secretory inactivity of a normal salivary gland also leads to increased formation of sialomicroliths. ${ }^{36}$ Sialomicroliths usually form in autophagosomes in normal salivary glands, enter the lumen and pass from the salivary gland in the saliva unnoticed. Occasionally, the sialomicroliths might become impacted resulting in local microobstruction. This microobstruction may cause atrophic foci and chronic sialendenitis. ${ }^{1,33,34,38}$ These microobstructions may clump together into a salivary stone. However, the incidence of sialomicroliths is not related to the duration of symptoms of sialolithiasis.

\section{Microorganisms}

Microorganisms do not seem to play a
Table 2 Characteristics of submandibular and parotid sialoliths ${ }^{2-5,16,17,20,21,25}$

\begin{tabular}{l|l|l}
\hline & $\begin{array}{l}\text { Submandibular } \\
\text { stone }\end{array}$ & Parotid stone \\
\hline Incidence & $72-95 \%$ & $4-28 \%$ \\
\hline Average size & $8.3 \mathrm{~mm}(2-30)$ & $6.4 \mathrm{~mm} \mathrm{(4-15)}$ \\
\hline Average age & $\begin{array}{l}43 \text { years } \\
(40.5-48)\end{array}$ & $\begin{array}{l}49.8 \text { years } \\
(47.8-52.6)\end{array}$ \\
\hline
\end{tabular}

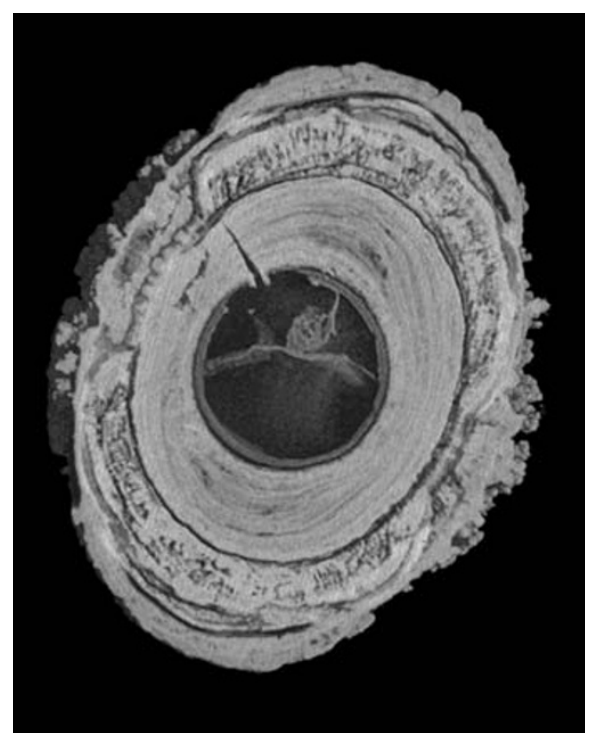

Fig. 2 Micro CT scan of a sialolith, showing an organic nucleus surrounded by laminated layers of organic and inorganic substances (courtesy of Professor Johan Aps, University of Washington, School of Dentistry)

significant role in the initiation of salivary stones, as very few studies identified microorganisms in the nuclei of sialoliths. ${ }^{31,39-42}$ However, in the intermediate and peripheral parts of sialoliths microorganisms have been identified, mostly oral commensal bacteria like Streptococcus or Peptostreptococcus species. ${ }^{14,29,39,43-46}$ The external surfaces of calculi removed from infected salivary glands, were found to be covered with a heavy accumulation of filamentous and rod shaped bacteria with a diameter of $0.5-1 \mu \mathrm{m} .{ }^{28,40,44}$

\section{Salivary gland anatomy}

The anatomical differences between Wharton's and Stenson's duct may favour the formation of sialoliths in the submandibular gland. Although the diameter of both ducts are comparable, Wharton's duct is longer and has a bow-shaped course in the cranial direction. ${ }^{21,47}$ This results in a flow against gravity, which may facilitate stasis of submandibular saliva. ${ }^{23,25,35}$ Furthermore, submandibular gland saliva is more viscous than parotid gland saliva, due to a higher mucin concentration. Additionally, saliva from the submandibular gland has a higher $\mathrm{pH}$, and contains twice as much calcium as parotid saliva. ${ }^{1,28,48,49}$ Mineralisation 
is supported by accumulation of calcium and an increase in $\mathrm{pH}$, which decreases the solubility of calciumphosphate in saliva. Together, these factors may favour mineralisation of a mucoid gel formed in the ductal system of a submandibular gland..$^{28,50}$

\section{PREDISPOSING FACTORS}

An altered saliva composition may predispose to the formation of salivary stones. It has been reported that the salivary protein content and viscosity of saliva is higher in patients with sialolithiasis than in unaffected individuals. ${ }^{51}$ Several studies showed higher calcium concentrations in saliva in patients with salivary stones than in a healthy control group. ${ }^{10,21,36,52}$ Saliva of patients with salivary stones also contains reduced concentrations of the crystallisation inhibitors phytate, magnesium and citrate, which may predispose to the formation of salivary stones. ${ }^{10,42}$ Salivary concentrations of sodium, chloride, nitrate, phosphate and sulphate did not differ from healthy individuals.

\section{Systemic factors}

Twenty-six percent of the patients with salivary stones have one or more comorbidities. ${ }^{3}$ Several studies suggested that patients with salivary stones suffer more frequently from kidney stones or stones in the gallbladder. ${ }^{17,21}$ However, in other studies the incidence of confirmed cholelithiasis and nephrolithiasis did not differ from the general population. ${ }^{3,25}$ The high prevalence of diabetes and hypertension in an Italian population with salivary stones did not correspond to other studies. ${ }^{3,17,53}$ Gout appears to be the only systemic disease predisposing to sialolith formation. ${ }^{1}$ Salivary stones in gout patients are predominantly composed of uric acid. ${ }^{19}$

A decreased salivary flow rate may facilitate the formation of a salivary stone. However, there is no increased incidence of sialolithiasis in patients suffering from Sjögren's syndrome. ${ }^{42}$ The use of diuretics predisposes to formation of salivary stones, because diuretics decrease the salivary flow rate. ${ }^{54}$ Twenty percent of the patients with salivary stones use diuretics, twice that of patients without salivary stones. ${ }^{25}$

Smoking may decrease the antimicrobial activity of saliva, resulting in an increased bacterial load and inflammation of the salivary duct and/or gland. Huoh et al. ${ }^{25}$ found a higher rate of smoking or history of smoking in patients with salivary stones than in the general population, although the difference did not reach statistical significance. Submandibular stones of smokers are also slightly larger (average diameter $8.7 \mathrm{~mm}$ ) than submandibular stones of nonsmokers $(7.9 \mathrm{~mm})$. On the other hand, the mean age of presentation of a salivary stone is higher in smokers (50.9 years) than in non-smokers (44.9 years). ${ }^{25}$

It has been suggested that residents of hard water areas are at increased risk of developing salivary calculi. However, there is no correlation between the incidence of salivary stones and the calcium content of water in different regions in England. ${ }^{55}$

\section{STRUCTURE}

Submandibular and parotid sialoliths consist of an amorphous, mineralised core or nucleus, with concentric laminated layers or shells of organic and inorganic substaces $^{21,23,28,41,44,49,50,56-59}$ (Fig. 2). The nucleus of the sialolith has a diameter between 0.5 and $1.5 \mathrm{~mm}$ and a softer consistence than the peripheral parts. ${ }^{19,28}$ The core is usually homogeneous but may contain substructures, indicating fusion of smaller structures like sialomicroliths. ${ }^{21,29}$ The concentric laminated layers are either homogenous or extremely irregular, suggesting that sialolith formation is an intermittent process. ${ }^{23,50}$ Scanning electron microscopy showed granular or globular, coarse structures with a diameter of 5-15 $\mu \mathrm{m}$ and pyramid structures on the surface of submandibular calculi. ${ }^{40,49,58}$ Hexagonal, needle-like and plate-shaped crystals on the surface of sialoliths have also been described. ${ }^{46}$

\section{BIOCHEMICAL COMPOSITION}

Sialoliths consist of both organic and inorganic material, but there is a great variation in the relative contribution. ${ }^{42,60}$ The organic matrix varies in different parts of sialoliths from 23 to $100 \%$ and is mainly present in the nucleus of the sialolith and the outer shell of the sialolith. ${ }^{25,28,36}$ Few sialoliths are constituted of only organic material; most salivary stones contain calcium phosphates, either as hydroxyapatite or carbonate apatite. ${ }^{52,61}$

The organic matrix comprises approximately $20 \%$ of the dry weight of parotid stones. Submandibular stones contain less organic material: approximately $9-12 \%$ of the dry weight. ${ }^{62,63}$ The organic part consists of collagen, neutral and acid glycoproteins, other proteins, lipids and carbohydrates such as glucose and mannose. ${ }^{33,60,61,63}$ In submandibular stones, protein contributes approximately $5 \%$ to the stone weight whereas lipids contribute $1 \% .^{61,63}$

\section{Proteins}

In submandibular stones, protein contributes approximately 5\% to the stone weight. The matrix of human submandibular stones contains higher levels of proteins than the matrix of parotid stones. ${ }^{63}$ Using immunoblotting techniques, Proctor et al. ${ }^{64}$ observed a large, unidentified glycoprotein in solubilised submandibular sialoliths. Lower molecular weight proteins, including statherin and acidic proline-rich protein, were also present in stones. These calciumbinding proteins are present in human submandibular saliva, and probably bind to calcium ions in sialoliths.

Amino acid analysis of the proteins in submandibular sialoliths showed relatively high levels of alanine, leucine, glutamine, aspartic acid, valine and glycine. Lysine, arginine, proline, methionine, cysteine, histidine, serine, isoleucine, phenylalanine, tyrosine and threonine were present in lower amounts. ${ }^{15,62}$

\section{Lipids}

Lipids are present in the organic matrix of both submandibular and parotid stones. ${ }^{65}$ The lipid content is not related to the weight of the stone. ${ }^{66}$ In parotid salivary stones, these lipids mainly comprise neutral lipids (74\%), glycolipids (17\%) and phospholipids (9\%). Of the neutral lipids, about 77\% are present as free fatty acids, $14 \%$ as cholesterol and small percentages as triglycerides and cholesterol esters. ${ }^{61}$ The phospholipid composition of sialoliths is comparable to that of plasma membranes and does not resemble lipids in saliva or bacterial membranes. ${ }^{66}$ Slomiany and co-workers ${ }^{61,63}$ suggested that the lipids and phospholipids are important for the initiation of the mineralisation of a salivary stone.

\section{Inorganic matrix}

Sialoliths are mainly composed of inorganic material. Submandibular stones contain between $70-80 \%$ and parotid stones around $50 \% .^{15,42,66,67}$

The mineral component is proportional to the size of the sialolith, suggesting that mineralisation of the organic matrix increases with time. ${ }^{36,42}$

Hydroxyapatite $\left(\mathrm{Ca}_{5}\left(\mathrm{PO}_{4}\right)_{3} \mathrm{OH}\right)$ is present in all submandibular stones, frequently together with whitlockite $\left(\mathrm{Ca}_{3}\left(\mathrm{PO}_{4}\right)_{2}\right)$. Octacalciumphosphate $\left(\mathrm{Ca}_{8} \mathrm{H}_{2}\left(\mathrm{PO}_{4}\right)_{6} \cdot 5 \mathrm{H}_{2} \mathrm{O}\right)$ and brushite $\left(\mathrm{CaHPO}_{4} \cdot 2 \mathrm{H}_{2} \mathrm{O}\right)$ are less often identified. Whitlockite is especially found in sialoliths from Wharton's duct and often present in the nucleus. Parotid salivary stones also contain always hydroxyapatite. Whitlockite and octacalcium phosphate are more frequently present in parotid stones than in submandibular stones. ${ }^{28,45,50,64,68,69}$

Minor inorganic components of sialoliths are potassium, sodium, ferrum, silicon, brimstone and chloride. ${ }^{10,70}$ Stones retrieved from an infected gland may also contain ammonium and magnesium. ${ }^{52}$

\section{DIAGNOSIS}

Most patients suspected of sialolithiasis 
will present in the clinic during an acute phase of the disease. A careful anamnesis and physical examination of the patient are important. The physical examination should include bimanual palpation of the floor of the mouth in a posterior to anterior direction for submandibular glands or an intraoral palpation around Stensen's duct for parotid glands. ${ }^{1,31,48,71}$ The affected gland may feel firm and tender. In case of a submandibular gland, the affected side of the floor of the mouth may be elevated and inflamed. ${ }^{26}$

In addition to an oral examination, several imaging techniques can be applied. Despite the relatively high percentage of inorganic material in salivary stones, between $80-95 \%$ of the submandibular stones and 43-60\% of the parotid stones are radiopaque. ${ }^{1,5,17,31}$ Demonstration of sialoliths by radiographic examination is effective in approximately $80 \%$ of the cases $^{72}$ (Fig. 3). The detection rates differ between intraoral occlusal radiographs and extra-oral panoramic radiographs. Extraoral radiographs will detect fewer salivary stones because many calculi will be projected superimposed on bony structures or teeth. ${ }^{73}$ This indicates that an occlusal radiograph is the most useful method for detection of a submandibular sialolith. ${ }^{74}$ Computer tomography (CT) and cone beam computer tomography (CB-CT) can detect any size of sialolith, but have the disadvantage of a relatively high radiation dose. ${ }^{73}$ Ultrasonography allows detection of stones with a diameter of $2 \mathrm{~mm}$ or more. ${ }^{1,473}$ This technique has the additional advantage that it also can be used during an acute episode of sialendenitis.

Radiolucent sialoliths can be imaged with sialography. A contrast agent is injected into the duct of the affected gland and subsequently radiographs are taken. Sialography is most frequently used for detection of parotid sialoliths. It is contraindicated during acute episodes of sialendenitis and in patients with an allergy to contrast media. Sialograms are up to $100 \%$ effective in detecting intraductal and intraglandular calculi. ${ }^{1,75}$

Sialendoscopy is a minimally invasive technique to visualise the salivary duct system, usually performed under general anaesthesia. An endoscope with a very small diameter $(0.6 \mathrm{~mm})$ is introduced into the duct after the orificium has been dilated with special instruments with increasing diameters from $0.8-1.6 \mathrm{~mm}$ (Figs 4 and 5). The endoscope has a rinse channel that can be used to flush the duct with saline or an antiinflammatory rinse. This flushing primarily results in a better image of the salivary ducts but may also have a therapeutic effect. ${ }^{76,77}$

\section{TREATMENT}

The primary objective in the treatment of

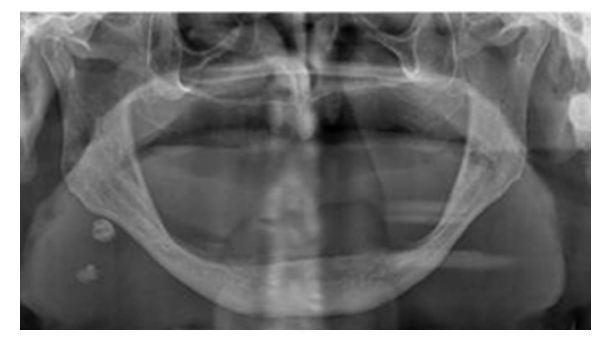

Fig. 3 Panoramic radiograph of an edentulous patient with sialoliths in the right submandibular gland (courtesy of Professor Johan Aps, University of Washington, School of Dentistry)

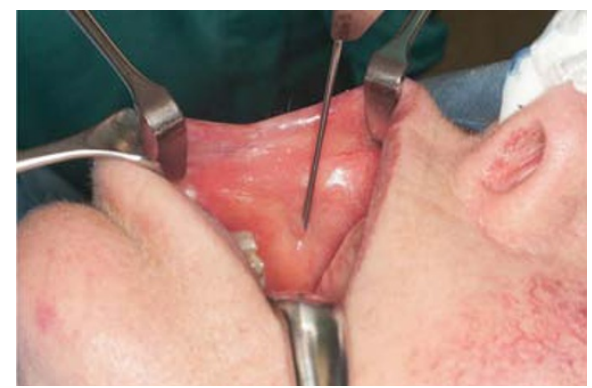

Fig. 4 The oroficium of the parotid gland is dilated and prepared for sialendoscopy with a special probe (courtesy of Dr Erik van der Meij, department of Oral-Maxillofacial Surgery, Medical Centre Leeuwarden)

sialolithiasis should be preservation of gland function in combination with a low level of complications and discomfort for the patient. ${ }^{78}$ Non-invasive conservative management of sialolithiasis consists of gland massage, in combination with use of sialogogues and irrigation. This treatment has the highest success rate when stones are small and located in the duct. When an infection is suspected, antibiotics should be prescribed. . $^{1,31,48}$

Nearly all intraductal submandibular and parotid stones can be removed by a relatively simple intraoral approach under local anaesthesia $^{5,31}$ (Fig. 6). This includes submandibular stones located near the knee of the duct. ${ }^{24}$ Transoral removal is treatment of choice in patients with stones that can be palpated bimanually and/or which are localised by ultrasound within the prehilar region of the gland. ${ }^{78,79}$ After stone removal, it is recommended that salivary gland massage is carried out several times a day, combined with a sour diet and sialogogues to stimulate the salivary flow. ${ }^{79}$ It is recommended to avoid use of sutures in the incised duct as this may increase the risk of scarring. ${ }^{71,73,75}$

Invasive management of sialolithiasis may consist of extracorporeal shock-wave lithotripsy, sialoendoscopy or surgical removal.

Most patients experience no complaints or discomfort, but a normal functioning gland, after sialolith therapy that does not include surgical removal of the gland..$^{80-82}$

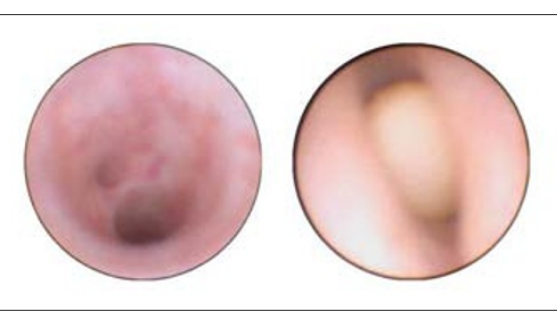

Fig. 5 Sialendoscopic images of the bifurcation of Stenson's duct (a) and a sialolith in Stenson's duct (b) (courtesy of Dr Erik van der Meij, department of Oral-Maxillofacial Surgery, Medical Centre Leeuwarden)

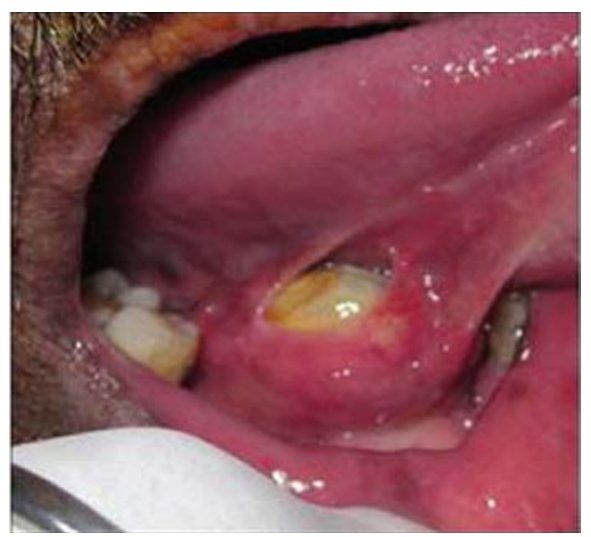

Fig. 6 Transoral removal of a submandibular sialolith after a surgical incision of $5 \mathrm{~mm}$ has been made in the oroficium of Wharton's duct (courtesy of Professor Johan Aps, University of Washington, School of Dentistry)

After transoral surgical removal of submandibular stones, the secretion rate of the treated gland is in 75\% of the cases similar to that of the contralateral gland. ${ }^{24}$ Recovery of function of the salivary gland is related to factors such as glandular infection, the diameter of the sialolith and the age of the patients. Patients with normal salivary secretion from a submandibular gland after transoral removal of a sialolith were significantly younger than those patients in which saliva secretion from the treated gland was decreased compared to the contralateral unaffected submandibular gland. The duration of symptoms before treatment was not related to recovery. ${ }^{11,24,83}$

Recurrence of sialoliths is rather uncommon, and is estimated to occur in $1-10 \%$ of the patients. ${ }^{17,72,78,79,84}$

1. Williams M F. Sialolithiasis. Otolaryngol Clin North Am 1999; 32: 819-834.

2. Levy D M, Remine W H, Devine K D. Salivary gland calculi. Pain, swelling associated with eating. J Am Med Assoc 1962; 181: 1115-1119.

3. Zenk J, Constantinidis J, Kydles S, Hornung J, Iro $\mathrm{H}$. Klinische und diagnostische Befunde bei der Sialolithiasis. HNO 1999; 47: 963-969.

4. Zenk J, Koch M, Klintworth N et al. Sialoendoscopy in the diagnosis and treatment of sialolithiasis: a study on more than 1000 patients. Otolaryngol Head Neck Surg 2012; 147: 858-863.

5. McGurk M, Escudier M P, Brown J E. Modern management of salivary calculi. Br J Surg 2005; 92: 107-112. 
6. Pace $\mathrm{C}$, Ward S. Incidental finding of sialolithiasis in the sublingual gland: a diagnostic dilemma. Dent Update 2011; 38: 704-705.

7. McGurk M, Escudier M P, Brown E. Modern management of obstructive salivary gland disease. Ann $R$ Australas Coll Dent Surg 2004; 17: 45-50.

8. Taher A A. The incidence and composition of salivary stones (sialolithiasis) in Iran: analysis of 95 cases - a short report. Singapore Dent J 1989; 14: 33-35.

9. Esser R J, Zecha J J. Submandibulaire speekselstenen. Ned Tijdschr Geneeskd 1976; 120: 817-821.

10. Su Y X, Zhang K, Ke Z, Zheng G, Chu M, Liao G. Increased calcium and decreased magnesium and citrate concentrations of submandibular/sublingual saliva in sialolithiasis. Arch Oral Biol 2010; 55: 15-20.

11. Nishi M, Mimura T, Marutani K, Noikura T. Evaluation of submandibular gland function by sialo-scintigraphy following sialolithectomy. J Oral Maxillofac Surg 1987; 45: 567-571.

12. Anneroth G, Hansen L S. Minor salivary gland calculi: a clinical and histopathological study of forty-nine cases. Int J Oral Surg 1983; 12: 80-89.

13. Yamamoto H, Sakae T, Takagi M, Otake S, Hirai G. Weddelite in submandibular gland calculus J Dent Res 1983; 62: 16-19.

14. Marchal F, Kurt A M, Dulguerov $P$, Lehmann W. Retrograde theory in sialolithiasis formation. Arch Otolaryngol Head Neck Surg 2001; 127: 66-68.

15. Harrill J A, King J S, Boyce W H. Structure and composition of salivary calculi. Laryngoscope 1959; 59: 481-492.

16. Escudier M P, McGurk M. Symptomatic sialadenitis and sialolithiasis in the English population, an estimate of the cost of hospital treatment. Br Dent J 1999; 186: 463-466.

17. Lustmann J, Regev E, Melamed Y. Sialolithiasis. A survey on 245 patients and a review of the literature. Int J Oral Maxillofac Surg 1990; 19: 135-138.

18. Gupta A, Rattan D, Gupta R. Giant sialoliths of submandibular duct: report of two cases with unusual shape. Contemp Clion Dent 2013; 4: 78-80.

19. Blatt I M, Denning R M, Zumberge J H, Maxwell J H. Studies in sialolithiasis. I. The structure and mineralogical composition of salivary gland calculi. Ann Otol Rhinol Laryngol 1958; 67: 595-617.

20. Rauch S, Gorlin R J. Diseases of the salivary glands. Oral pathology 1970; 962

21. Harrison J D. Causes, natural history, and incidence of salivary stones and obstructions. Otolaryngol Clin NAm 2009; 42: 927-947.

22. Bullock K N. Parotid and submandibular duct calculi in three successive generations of one family. Postgrad Med J 1982; 58: 35-36.

23. Hiraide $F$, Nomura $Y$. The fine surface structure and composition of salivary calculi. Laryngoscope 1980: 90: 152-158.

24. Van den Akker H P, Busemann-Sokole E. Submandibular gland function following transoral sialolithectomy. Oral Surg Oral Med Oral Pathol 1983; 56: 351-356.

25. Huoh K C, Eisele D W. Etiologic factors in sialolithiasis. Otolaryngol Head Neck Surg 2011; 145: 935-939.

26. Seldin H M, Seldin D, Rakower W. Conservative surgery for the removal of salivary calculi. Oral Surg Oral Med Oral Pathol 1953; 6: 579-587.

27. Pullon P A, Miller A S. Sialolithiasis of accessory salivary glands: review of fifty-five cases. J Oral Surg 1972; 30: 832-834.

28. Teymoortash A, Buck P, Jepsen $H$, Werner J A. Sialolith crystals localized intraglandularly and in the Wharton's duct of the human submandibular gland: an X-ray diffraction analysis. Arch Oral Biol 2003; 48: 233-236.

29. Jensen J L, Howell FV, Rick G M, Corneal R W. Minor salivary gland calculi. Oral Surg Oral Med Oral Pathol 1979; 47: 44-50.

30. Yamane $G M$, Scharlock $S E$, Jain $R$, Sundaraj $M$, Chaudry A P. Intra-oral minor salivary gland sialolithiasis. J Oral Med 1984; 39: 85-90.

31. Siddiqui S J. Sialolithiasis: an unusually large submandibular salivary stone. Br Dent J 2002; 193: 89-91.

32. Epivatianos A, Harrison $H$, Dimitriou T. Ultrastructural and histochemical observations on microcalculi in chronic submandibular sialoadenitis Oral Pathol 1987: 16: 514-517.

33. Epivatianos A, Harrison J D. The presence of microcalculi in normal human submandibular and parotid salivary glands. Arch Oral Biol 1989; 34: 261-265.

34. Harrison J D, Epivatianos A, Bhatia S N. Role of microliths in the aetiology of chronic submandibular sialadenitis: a clinicopathological investigation of 154 cases. Histopathology 1997; 31: 237-251.

35. Bodner L. Parotid sialolithiasis. J Laryngol Otol 1999; 113: 266-267.

36. Harrison J D. Histology and pathology of sialolithiasis. Salivary gland diseases New York, USA, Thieme, 2005: 71-78.

37. Mimura M, Tanaka N, Ichinose $S$, Kimijima $Y$, Amagasa T. Possible etiology of calculi formation in salivary glands: biophysical analysis of calculus. Med Mol Morphol 2005; 38: 189-195.

38. Triantafyllou A, Harrison J D, Garrett J R. Microliths in the parotid of ferret investigated by electron microscopy and microanalysis. Int J Exp Path 2009; 90: 439-447.

39. Anneroth $G$, Eneroth $C M$, Isacsson $G$. Crystalline structure of salivary calculi. A microradiographic and microdiffractometric study. J Oral Pathol 1975; 4: $266-272$

40. Lustmann J, Shteyer A. Salivary calculi: ultrastructural morphology and bacterial etiology. J Dent Res 1981; 60: 1386-1395.

41. Isacsson G, Hammarström L. An enzyme histochemical study of human salivary duct calculi. J Oral Pathol 1983; 12: 217-222.

42. Proctor G B, Osailan S M, McGurk M, Harrison J D. Sialolithiasis - pathophysiology, epidemiology and aetiology. In Nahlieli 0 (ed) Modern management of preserving the salivary glands. pp 91-142. Israel: Isradon Publishing House, 2007.

43. Anneroth $\mathrm{G}$, Eneroth C M, Isacsson G, Lundquist P G. Ultrastructure of salivary calculi. Scand J Dent Res 1978; 86: 182-192.

44. Teymoortash A, Wollstein A C, Lippert B M, Peldszus $R$, Werner J A. Bacteria and pathogenesis of human salivary calculus. Acta Otolaryngol 2002; 122: 210-214.

45. Marchal F, Dulquerov P. Sialolithiasis management - the state of the art. Arch Otolaryngol Head Neck Surg 2003; 129: 951-956

46. Kasaboglu O, Nuray E, Tümer C, Akkocaoglu M. Micromorphology of sialoliths in submandibular salivary gland: a scanning electron microscope and $X$-ray diffraction analysis. J Oral Maxillofac Surg 2004; 62: 1253-1258.

47. Zenk J, Hosemann W G, Iro H. Diameters of the main excretory ducts of the adult human submandibular and parotid gland: a histologic study. Oral Surg Oral Med Oral Pathol Oral Radiol Endod 1998; 85: 576-580.

48. Pollack C V, Severance H W. Sialolithiasis: case studies and review. J Emergency Med 1990; 8: 561-565.

49. Tanaka N, Ichinose S, Adachi Y, Mimura M, Kimijima Y. Ultrastructural analysis of salivary calculus in combination with X-ray microanalysis. Med Electron Microsc 2003; 36: 120-126.

50. Anneroth G, Eneroth C M, Isacsson G. Morphology of salivary calculi. The distribution of the inorganic component. J Oral Pathol 1975; 4: 257-265.

51. Afanas'ev V V, Tkalenko A F, Abdusalamov M R. Analysis of salivary pool composition in patients with different results of sialolithiasis treatment by sialolithotripsy. Stomatologiia 2003; 82: 36-38.

52. Grases F, Santiago C, Simonet B M, Costa-Bauza A. Sialolithiasis: mechanism of calculi formation and etiologic factors. Clin Chim Acta 2003; 334: 131-136.

53. Laforgia P D, Favia G F, Chiaravalle N, Lacaita M G, Laforgia A. Clinico-statistical, morphologic and microstructural analysis of 400 cases of sialolithiasis. Minerva Stomatol 1989; 38: 1329-1336.

54. Nederfors T, Nauntofte B, Twetman S. Effects of furosemide and bendroflumethiazide on saliva flow rate and composition. Arch Oral Biol 2004; 49: 507-513.

55. Sherman J A, McGurk M. Lack of correlation between water hardness and salivary calculi in England. Br J Oral Maxillofac Surg 2000; 38: 50-53.
56. Perrotta R J, Williams J R, Selfe R W. Simultaneous bilateral parotid and submandibular gland calculi. Arch Otolaryngol Head Neck Surg 1978; 104: 469-470.

57. Vignoles M, Faure J, Legros R, Bonel G, Guichard M. Identification of the mineral constituents of various salivary calculi by study of their thermal behavior. $J$ Biol Buccale 1980; 8: 103-115.

58. Yamamoto H, Sakae T, Takagi M, Otake S. Scanning electron microscopic and X-ray microdiffractometeric studies on sialolith-crystals in human submandibular glands. Acta Pathol Jpn 1984; 34: 47-53.

59. Kodaka T, Debari K, Sano T, Yamada M. Scanning electron microscopy and energy-dispersive $\mathrm{X}$-ray microanalysis studies of several human calculi containing calcium phosphate crystals. Scanning Microsc 1994; 8: 241-256

60. Jayasree R S, Gupta A K, Vivek V, Nayar V U. Spectroscopic and thermal analysis of a submandibular sialolith of Wharton's duct resected using Nd: YAG laser. Lasers Med Sci 2008; 23: 125-131.

61. Slomiany B L, Murty V L N, Aono M, Slomiany A, Mandel I D. Lipid composition of the matrix of human submandibular salivary gland stones. Arch Oral Biol 1982; 27: 673-677

62. Osuoji C I, Rowles S L. Studies on the organic composition of dental calculus and related calculi. Calcif Tissue Res 1974; 16: 193-200.

63. Slomiany B L, Murty V L N, Aono M, Slomiany A, Mandel I D. Lipid composition of human parotid salivary gland stones. J Dent Res 1983; 62: 866-869.

64. Proctor G B, McGurk M, Harrison J D. Protein composition of submandibular stones. J Dent Res 2005; 84(Splss): Ab0218.

65. Mandel I D, Eisenstein A. Lipids in human salivary secretions and salivary calculus. Arch Oral Biol 1969 14: 231-233.

66. Boskey A L, Boyan-Salyers B D, Burstein LS, Mandel I D. Lipids associated with mineralization of human submandibular gland sialoliths. Arch Oral Biol 1981; 26: 779-785.

67. Ekberg 0, Isacsson G. Chemical analysis of the inorganic component of human salivary duct calculi. Arch Oral Biol 1981; 26: 951-953.

68. Hohling H J, Schöpfer H. Morphological investigations of apatite nucleation in hard tissue and salivary stone formation. Naturwissenschaften 1968; 55: 545

69. Burstein L S, Boskey A L, Tannenbaum P J, Posner A S, Mandel I D. The crystal chemistry of submandibular and parotid salivary gland stones. J Oral Pathol 1979; 8: 284-291.

70. Szalma J, Böddi K, Lempel E et al. Structural analysis and protein identification from submandibular salivary stones. J Dent Res 2011; A391.

71. Whinery J. Salivary calculi. J Oral Surg 1954; 12: 43-47.

72. Ellies M, Laskawi R, Arglebe C, Schott A. Surgical management of nonneoplastic diseases of the submandibular gland. A follow-up study. Int J Oral Maxillofac Surg 1996; 25: 285-289.

73. Bodner L. Salivary gland calculi: diagnostic imaging and surgical management. Comp Contin Educ Dent 1993; 14: 572-584

74. Baurmash H D. Submandibular salivary stones: current management modalities. J Oral Maxillofac Surg 2004; 62: 369-378

75. McKenna J P, Bostock D J, McMenamin P G. Sialolithiasis. Am Fam Physician 1987; 36: 119-125.

76. Bowen M A, Tauzin M, Kluka E A, Nuss D W, DiLeo M, McWhorter A J, Schaitkin B, Walvekar R R. Diagnostic and interventional sialendoscopy: a preliminary experience. Laryngoscope 2011; 121: 299-303.

77. Strychowsky J E, Sommer D D, Gupta M K, Cohen $\mathrm{N}$, Nahlieli O. Sialendoscopy for the management of obstructive salivary gland disease: a systematic review and meta-analysis. Arch Otolaryngol Head Neck Surg 2012; 138: 541-547.

78. Zenk J, Constantinidis J, Al-Kadah B, Iro H. Transoral removal of submandibular stones. Arch Otolaryngol Head Neck Surg 2001; 127: 432-436.

79. Zenk J, Gottwald F, Bozzato A, Iro H. Speichelsteine der Glandula submandibularis. Setinentfernung mit Organerhalt. HNO 2005; 53: 243-249. 
80. Isacsson G, Ahlner B, Lundquist PG. Chronic sialadenitis of the submandibular gland. A retrospective study of 108 case. Arch Otorhinolaryngol 1981; 232: 91-100.

81. Yoshimura Y, Morishita T, Sugihara T. Salivary gland function after sialolithiasis: scintigraphic examination of submandibular glands with
99mTc-pertechnetate. J Oral Maxillofac Surg 1989; 47: 704-710.

82. Makdissi J, Escudier MP, Brown JE, Osailan S, Drage N, McGurk M. Glandular function after intraoral removal of salivary calculi from the hilum of the submandibular gland. Br J Oral Maxillofac Surg 2004; 42: 538-541.

83. Zenk J, Koch M, Mantsopoulos K, Klintworth $N$,
Schapher M, Iro H. Der Stellenwert der extrakorporalen Stosswellen-lithotripsie bei der Therapie der Sialolithiasis. HNO 2013; 61: 306-311.

84. Nahlieli O, Baruchin A M. Long-term experience with endoscopic diagnosis and treatment of salivary gland inflammatory diseases. Laryngoscope 2000; 110: 988-993. 